\title{
Nutrient-limited growth of the coral reef macroalga Sargassum baccularia and experimental growth enhancement by nutrient addition in continuous flow culture
}

\author{
Britta Schaffelke*, David W. Klumpp \\ Australian Institute of Marine Science, PMB 3, Townsville MC, Queensland 4810, Australia
}

\begin{abstract}
The observed high biomass of Sargassum species and other fleshy macroalgae on nearshore coral reefs in the Great Barrier Reef (Australia) raises the concern that this may be a sign of a phase shift from hard coral to dominance by algae, thus indicating the degradation of these reefs. Nearshore reefs are, due to their geographical position, exposed to inputs of nutrients and particles from mainland run-off. This study estimated the limiting and optimum nutrient concentrations for the growth of Sargassum baccularia under continuous supply of ammonium and phosphate. To assess the nutrient situation in the field, critical and subsistence levels of tissue nutrients as determined in cultures were compared with field tissue nutrient levels, and a 'mini budget' was estimated that compares nutrient requirements with nutrient supply. The growth rates of $S$ baccularia almost doubled within the narrow window of substrate concentrations from $3 \mu \mathrm{M}$ ammonium plus $0.3 \mu \mathrm{M}$ phosphate to $5 \mu \mathrm{M}$ ammonium plus $0.5 \mu \mathrm{M}$ phosphate. Lower and, unexpectedly, higher nutrient concentrations resulted in reduced growth rates. Field thalli of $S$. baccularia were always sufficiently supplied with $\mathrm{N}$ and $\mathrm{P}$ to show positive growth rates. However, field growth was both $\mathrm{N}$ - and P-limited, particularly in austral summer, when fast growth of $S$. baccularia occurs. This was indicated by tissue $N$ and $P$ concentrations that fell below the respective critical nutrient values, and estimated nutrient demands that exceeded the nutrients available from the water column. We suggest that if land-derived nutrient inputs increased, $S$. baccularia would become nutrient-sufficient, especially during the summer wet season. This may increase the competitive potential of this species to colonise larger areas on the nearshore reefs.
\end{abstract}

KEY WORDS: Sargassum - Nutrient-limited · Growth - Tissue nutrients · Coral reefs

\section{INTRODUCTION}

Macroalgae are key components in many coral reef communities. High feeding pressure from herbivores generally diminishes macroalgae to the species rich 'algal turf' typical of coral reefs (Hatcher 1988, 1990). However, large brown algae occur in high abundances on nearshore reefs of the Great Barrier Reef, Australia (GBR), especially on reefs fringing granite continental

•E-mail: b.schaffelke@aims.gov.au islands (Morrissey 1980, McCook et al. 1997, Schaffelke \& Klumpp 1997a). Among these macroalgae the genera Cystoseira, Hormophysa, Sargassum, and Turbinaria are strikingly abundant in summer (MartinSmith 1993, Vuki \& Price 1994, Schaffelke \& Klumpp 1997 a) and are often regarded as diminishing the aesthetic value of nearshore reefs

In the past $20 \mathrm{yr}$, several cases of algal overgrowth have been reported on reefs in the Caribbean, and in Hawaii and Florida (Smith et al. 1981, Lapointe 1989, Hughes 1994). These blooms were attributed to anthropogenic nutrient inputs, herbivore reduction, 
catastrophic events, or a combination of all of these factors. Top-down control mechanisms, i.e. herbivory, have been favoured in explaining the presence or absence of macroalgae on coral reefs (e.g Hay 1984, Hughes 1994, McCook 1996, 1997). However, there is evidence that elevated nutrients, either derived from human activity or by natural upwelling events, have been the prime cause for some macroalgal blooms (Smith et al. 1981, Pastorok \& Bilyard 1985, Rose \& Risk 1985, Lapointe \& O'Connell 1989, Szmant \& Forrester 1996, Lapointe et al. 1997). Also, on a high latitude coral reef with naturally high nutrient levels, high abundance and productivity of macroalgae have been reported (Smith 1981, Crossland et al. 1984). The interaction of both top-down and bottom-up mechanisms has been recognised as the most likely interpretation for macroalgal abundance on coral reefs but has been poorly studied (Hatcher \& Larkum 1983, Littler \& Littler 1984, Miller \& Hay 1996).

On the GBR, no harmful macroalgal bloom of large extent has been reported to date. The higher abundance of large brown algae on nearshore reefs of the $\bar{G} \bar{B} \bar{K}$ has been attributed to less grazing pressure by herbivorous fish compared to reefs further offshore (Scott \& Russ 1987, McCook 1996). However, the assumption that macroalgal abundance on GBR nearshore reefs is increasing has been disputed mainly because long term datasets are lacking (discussed in McCook \& Price 1997).

Nutrient concentrations in the water column of the GBR lagoon are still relatively low (Furnas et al. 1995, Furnas \& Mitchell 1997). There are, however, some studies reporting higher water column nutrient levels, in particular in the vicinity of fringing reefs (Hatcher \& Hatcher 1981, Crossland \& Barnes 1983, Staunton Smith \& Johnson 1995). In inshore waters of the GBR, only particulate nutrient concentrations have been reported to be higher than in midshelf and outer shelf waters (Furnas et al. 1995, Klumpp et al. in press). On the mainland adjacent to the GBR, increased use of agricultural fertiliser during this century has been reported (Pulsford 1996). Increased nutrient loads in rivers have been estimated and are considered to be the result of farming and grazing activities (Moss et al. 1992, Brodie 1997). Bell (1991, 1992), Brodie (1995) and Bell \& Elmetri (1995) discuss the threat of eutrophication for the GBR lagoon, mainly based upon changes in water column chlorophyll concentrations used as indicators of elevated nutrient levels. However, a recent compilation of GBR chlorophyll data over the past $20 \mathrm{yr}$ shows highly variable data without a distinct trend towards higher levels (Brodie et al. 1997).

Because of their proximity to the mainland, nearshore reefs of the GBR are particularly subject to receiving land run-off. If macroalgae are nutrient- limited at these sites, increased nutrient availability may increase the potential for enhanced macroalgal growth. The objective of the present study was to evaluate the effect of enhanced nutrients on the growth of the large fucoid alga Sargassum baccularia (Mertens) C. Agardh, which dominated the macrophyte biomass at our study locations (Schaffelke \& Klumpp 1997a). The objective of the experiments was to determine limiting and optimum concentrations of available nutrients (nitrogen, $N$ and phosphorus, $P$ ) for growth of $S$. baccularia in experiments under continuous nutrient supply. To assess $\mathrm{N}$ - and P-limitation in the field, we determined critical and subsistence levels of these nutrients in algal tissues in the experimental cultures (according to Hanisak 1979 and Fujita et al. 1989, respectively) and compared the values with tissue nutrient levels in field thalli of the same species. We also estimated a 'mini budget', which compared the in situ nutrient requirements of $S$. baccularia with the nutrient supply by uptake of inorganic nutrients available in the field.

\section{MATERIALS AND METHODS}

Collection of algae and water samples. All samples were collected from reef flats of fringing coral reefs of 3 nearshore continental islands in the central Great Barrier Reef, Australia (Brook Islands, $146^{\circ} 17^{\prime} \mathrm{E}$, $18^{\circ} 09^{\prime} \mathrm{S}$; Fantome Island, $146^{\circ} 31^{\prime} \mathrm{E}, 18^{\circ} 41^{\prime} \mathrm{S}$; and Great Palm Island, $146^{\circ} 35^{\prime} \mathrm{E}, 18^{\circ} 41^{\prime} \mathrm{S}$ ).

For tissue nutrient analyses 2 types of plant material were collected from Sargassum baccularia at each of the 3 field locations: (1) young, basal shoots, which emerge from the holdfast tissue and (2) distal parts of older shoots, bearing branches and vesicles. For culture experiments, basal shoots of $S$. baccularia thalli at Great Palm Island were cut and kept in flowing seawater during transport and later in an outdoor tank at ambient light and temperature until used.

Water samples for analyses of standing concentrations of nutrients were taken at Great Palm Island at each of 3 stations, separated by approximately $50 \mathrm{~m}$. At each station, samples were taken in triplicate at high tide $( \pm 1 \mathrm{~h})$. For each sample, a $25 \mathrm{ml}$ plastic syringe was filled at a depth of 1.5 to $2 \mathrm{~m}$ (about $50 \mathrm{~cm}$ away from the sediment) by a snorkeller. The water was filtered immediately through an acid-washed, precombusted $0.45 \mu \mathrm{m} \mathrm{GF} / \mathrm{F}$ filter into $10 \mathrm{ml}$ plastic tubes, put on ice, and frozen after about $30 \mathrm{~min}$. Each sample was analysed for ammonium, nitrate, nitrite and phosphate using standard automated techniques (Ryle et al. 1981). For the calculation of the nutrient 'mini budget', we used the average concentrations of ammonium, nitrite and nitrate (DIN) and phosphate of each 9 sam- 
ples from 8 sampling occasions between June 1995 and June 1996 at Great Palm Island.

Culture experiments. Sargassum baccularia cultures were kept in a temperature controlled room at $30^{\circ} \mathrm{C}$ (in situ water temperature during summer growth maximum; Schaffelke \& Klumpp 1997a) and a light intensity of $300 \mu \mathrm{mol}$ photons $\mathrm{m}^{-2} \mathrm{~s}^{-1}$ (approximate saturation irradiance of photosynthesis of Sargassum species at the study sites; Klumpp et al. in press) with a photoperiod of $12 \mathrm{~h}$.

To minimise the number of epiphytes, basal shoots of Sargassum baccularia were pre-treated according to the following protocol: (1) microscopic check for macroepiphytes (magnification $10 \times$ ): discard if visible epiphytes present, (2) wipe with soft tissue, (3) wash in filtered seawater, (4) brief wash in fresh water, (5) wash in sterile seawater, (6) 2 min bath in $5 \%$ betadine in sterile seawater, (7) wash in sterile seawater. Before they were subjected to experimental conditions, the shoots recovered for at least $48 \mathrm{~h}$ in sterile seawater that was exchanged twice per day. A pilot study assured that, after the recovery period, thalli subjected to this cleaning protocol showed growth rates similar to untreated thalli.

Water used for the experiments was collected from the lagoon of the central GBR in about $2 \mathrm{~m}$ depth, at least $30 \mathrm{~km}$ offshore from islands or reefs. Sufficient water for 1 experimental run was filtered immediately at collection $(0.5 \mu \mathrm{m})$ and stored in polyethylene carboys at $4^{\circ} \mathrm{C}$ in the dark. Prior to use, seawater was autoclaved in $20 \mathrm{l}$ polycarbonate carboys for $1 \mathrm{~h}$ at $121^{\circ} \mathrm{C}$. Generally, this seawater had concentrations of inorganic nutrients close to or below the detection limits. Batches with higher nutrient concentrations were not used.

Continuous flow culture: Sargassum baccularia shoots were cultivated in $500 \mathrm{ml}$ Schott flasks with lids fitted with glass tubes for aeration and for inflowing and outflowing culture medium. The medium was supplied at a flow rate of approx. $0.51 \mathrm{~h}^{-1}$ from a $25 \mathrm{l}$ holding carboy with a peristaltic pump (Masterflex, ColeParmer Instrument Co.). Each experimental run accommodated 8 culture flasks with 2 subsample shoots each, supplied by 4 holding carboys. There were 4 replicate flasks for each nutrient treatment. Nutrients were added as ammonium chloride and sodium dihydrogen phosphate. Daily water samples were taken from each holding carboy for analyses of ammonium and phosphate concentrations (Koroleff 1983a, b). The Schott flasks were exchanged twice a week for fresh flasks that had been washed with $50 \%$ sulphuric acid and autoclaved. All tubing was washed with ethanol every $3 d$; once a week fresh, sterilised tubing was fitted. In the first week, $0.1 \%$ germanium dioxide was added to the medium to suppress diatom growth.
The fresh weight of each shoot was determined at the start and at the end of the 3 wk experimental period. The shoots were blotted dry with soft paper towel, weighed and returned immediately to seawater. Growth was determined as mass-specific growth rate per day. To keep the weight in each replicate flask at about $1.5 \mathrm{~g}$ fresh weight, shoots were trimmed every $5 \mathrm{~d}$, leaving the apical meristems intact. Pilot trials showed that the trimming did not influence the growth rates of Sargassum baccularia shoots, i.e. the massspecific growth rates of trimmed and non-trimmed shoots were similar.

The concentration of nitrogen and phosphorus in Sargassum baccularia tissue was analysed (see below) in samples taken at the start and end of each experiment. The critical nutrient concentration was estimated as the tissue nutrient concentration where maximum growth was just limited (after Hanisak 1979).

After about 1 wk adaptation in the experimental concentrations, uptake rates were calculated from the differences in nutrient concentrations of the inflowing and the outflowing seawater. At the end of Weeks 1, 2, and 3 of each experimental run, triplicate water samples were taken from each culture flask for both ammonium and phosphate analyses. For the calculation of the kinetic parameters, we used the mean of the uptake rates obtained for each flask. The kinetic parameters $K_{\mathrm{m}}$ and $V_{\text {max }}$ of the Michaelis-Menten hyperbolic equation and the respective confidence limits were calculated by a weighted linear regression technique (Wilkinson 1961). To calculate uptake rates at low substrate concentrations, which was required in deriving the nutrient 'mini budget', we estimated the initial slope of the hyperbolic equation, $\alpha$, which equals the quotient of $K_{\mathrm{m}}$ and $V_{\max }$ (suggested by Healey 1980 and Harrison et al. 1989). To determine nutrient uptake during the night, 1 set of samples from each of the experimental nutrient treatments $1 / 0.1$, $5 / 0.5,10 / 1,22 / 2.2 \mu \mathrm{M}$ ammonium/ $\mu \mathrm{M}$ phosphate was taken during the dark phase. The uptake rates of the night samples were compared to uptake rates from the same flasks sampled during daytime. All other water samples for the determination of uptake rates were taken during the light phases.

Starvation experiment: To determine subsistence concentrations of nitrogen and phosphorus, i.e. tissue nutrient levels at zero growth rates (after Fujita et al. 1989), Sargassum baccularia shoots were kept under conditions with minimal nutrient supply (natural seawater without detectable inorganic nutrients but with organic nutrients). This also provided an estimate of the nutrient storage capacity, i.e. the length of time that growth can be sustained without external inorganic nutrient supply (Fujita 1985). Pretreated shoots (see cleaning protocol) were kept in aerated $500 \mathrm{ml}$ 
Schott flasks in natural seawater without detectable inorganic nutrients. The seawater was exchanged every second day and was enriched with vitamins and trace metals (Provasoli enrichment without nutrients, modified from recipe in Starr \& Zeikus 1993). To obtain mass-specific growth rates, the fresh weights of the experimental shoots were determined every $5 \mathrm{~d}$ for $30 \mathrm{~d}$. At the start of the experiment 14 replicate bottles were set up, with 3 subsample shoots each. Every $5 \mathrm{~d}$, 1 shoot was removed from each of 3 haphazardly selected flasks for analyses of tissue nutrients (see below). The 3 removed shoots were replaced with shoots from one of the other flasks, which was then discarded. This procedure resulted in the reduction of the total number of flasks after each sampling, but it ensured that until the end of the experiment 5 flasks with 3 subsample plants each were present for growth measurements.

Tissue nutrient analyses. Sargassum baccularia tissue was dried at $60^{\circ} \mathrm{C}$ for $24 \mathrm{~h}$, ground with a mortar and pestle into a fine powder and stored at $-18^{\circ} \mathrm{C}$ until analysed. Total carbon and nitrogen were analysed with an ANTEK C/N anaiyser. For totai phosphorus, about $4 \mathrm{mg}$ of ground tissue was combusted for $1 \mathrm{~h}$ at $450^{\circ} \mathrm{C}$ and extracted with $25 \mathrm{ml}$ purified water for $12 \mathrm{~h}$ at $4^{\circ} \mathrm{C}$. The extract was filtered and analysed for total phosphorus (Koroleff 1983c). For the determination of water soluble phosphorus the same method was used, only with uncombusted ground tissue. This soluble phosphorus presumably consisted of both phosphate and polyphosphates, both of which are assumed to be the major dynamic phosphorus stores in macroalgae (Lundberg et al. 1989, Chopin et al. 1990, Walsh \& Hunter 1992). We refer to this fraction of total $P$ in algal tissue as storage $\mathrm{P}$. It is considered to be equivalent to the physiological pool plus the storage pool that Hanisak (1983) defined for tissue nitrogen.

Field growth rates. At 8 occasions from June 1995 to June 1996, shoots with a length of 4 to $8 \mathrm{~cm}$ were cut, each from the base of an individual Sargassum baccularia thallus. Twenty excised shoots were fixed with rubber bands to plastic pegs embedded in concrete blocks, which were then placed in the Sargassum zone at Great Palm. Island. After 4 to 6 wk, the lengths of the shoots were measured to the nearest mm using a calliper. Complete loss or severe damage of these shoots. presumably due to grazing, occurred relatively often, but at least 10 shoots were always present for growth measurements. For the calculation of mass-specific growth rates, length data (in $\mathrm{cm}$ ) were converted to fresh weight (FW) data (in gl using a linear function obtained from measurements of 300 shoots of S. baccularia: $\mathrm{FW}=0.23 \times$ length $-0.1, \mathrm{r}^{2}=0.81$.

Data analyses. All data were analysed with the statistical package SuperANOVA 1.11 (Abacus Concepts
Inc 1989-90). Error estimates of means represent $95 \%$ confidence limits, unless otherwise stated. Data were checked for homogeneity of variances and, if necessary, log transformed. For steady state cultures, the response variables (growth rate and tissue nutrient concentration) wert analysed using 1-way ANOVA with experimental nutrient concentration as a fixed factor. Tissue nutrient levels of field plants were analysed using 2-way ANOVA for each sampling location, with sampling time and tissue type (basal or distal tissue) as fixed factors. To qualify the result of a significant ANOVA, the differences between treatment means were compared using the Tukey-Kramer multiple comparison procedure at the $5 \%$ significance level. The SuperANOVA computing procedure for this post hoc test accounts for unequal sample numbers (SuperANOVA manual, Abacus Concepts Inc. 1989). In the 'Results' the term 'significant' refers to significantly difterent means, tested with the TukeyKramer test after a preceding ANOVA. Nutrient uptake rates in the light and in the dark were compared using a paired $t$-test. The samples from each nutrient ireaimeni were iesied separaiely. Each pais was formed by the light and dark uptake rates obtained from the same culture flask ( $n=4$ per treatment).

To obtain an overview of the nutrient status of Sargassum baccularia at Great Palm Island, we synthesised the available data into a 'mini budget'. Several assumptions were necessary for the calculations. The nutrient requirements of $S$. baccularia were calculated using the in situ growth rates and the corresponding tissue nitrogen and phosphorus concentrations. The nutrient supply was estimated as the daily nutrient uptake of field plants. This was calculated from the in situ nutrient concentrations of the water column and the initial slope, $\alpha$, of the ammonium or phosphate uptake kinetics obtained in the laboratory. For this calculation we assumed that the 'snapshot' nutrient data that we obtained for 1 day in each sampling month were representative for the whole month. Since we only had data for the uptake of ammonium, we assumed in the 'mini budget' similar uptake rates for all DIN species. A further assumption was that the nutrient uptake rates were similar during day and night.

\section{RESULTS}

\section{Culture experiments with continuous nutrient supply}

The growth of Sargassum baccularia shoots was significantly enhanced in the narrow window of substrate concentrations from 3/0.3 to 5/0.5 ( $\mu \mathrm{M}$ ammonium/ $\mu \mathrm{M}$ phosphate; Fig. 1a). Lower and, unexpectediy, also 

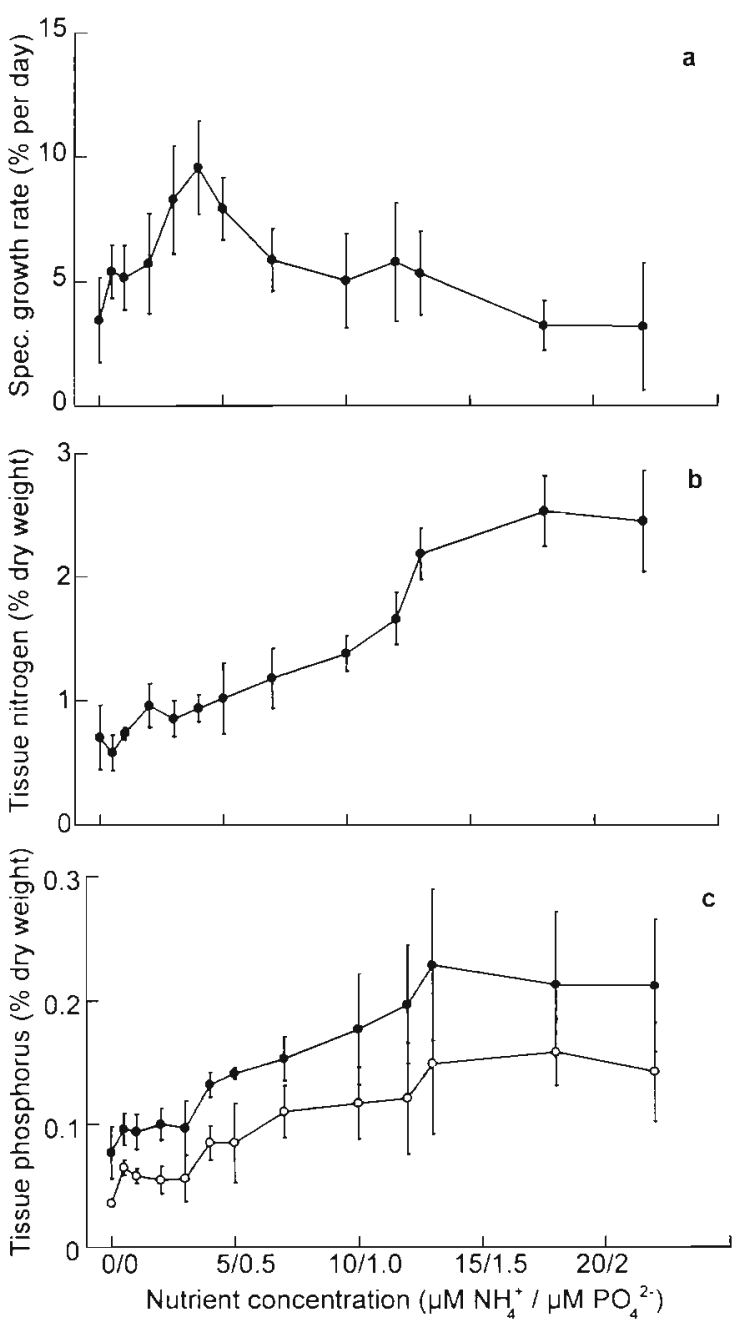

Fig. 1. Sargassum baccularia. Growth and mutrient status in culture with continuous supply of ammonium and phosphate enriched medium (flow rate $500 \mathrm{ml} \mathrm{h}^{-1}$ ). (a) Mass-specific growth rates, (b) total tissue nitrogen, (c) total tissue phosphorus ( $\bullet$ ) and soluble tissue phosphorus (o). Data are means ( $\mathrm{n}=$ 4) with $95 \%$ confidence intervals

higher nutrient concentrations resulted in reduced growth rates. Culture in the treatment $4 / 0.4$ resulted in significantly higher growth rates compared to shoots cultured in $0 / 0$ to $2 / 0.2$ and $7 / 0.7$ to $22 / 2.2$, and shoots in the treatments $3 / 0.3$ and $4 / 0.4$ had higher growth rates than shoots in $0 / 0$ to $1 / 0.1$ and $10 / 1$ to $22 / 2.2$ (1-way ANOVA, $\left.F_{12,44}=13.4, \mathrm{p}<0.05\right)$.

The concentration of nitrogen in Sargassum baccularia tissue (tissue $\mathrm{N}$ ) increased with increased ammonium supply (Fig. 1b). Tissue $\mathrm{N}$ in shoots cultured in the treatments $0 / 0$ to $5 / 0.5$ was significantly lower than in shoots from the treatments $10 / 1$ to $22 / 2.2$ (1-way ANOVA, $F_{12,39}=93.6, p<0.05$ ). The concentration of tissue $\mathrm{N}$ became saturated at a level of about $2.5 \%$ of dry weight (DW) (treatments $18 / 1.8$ and 22/2.2). As with tissue $N$, tissue $P$ increased with increasing phosphate supply, and the tissue became saturated at about $0.22 \%$ P of DW (Fig. 1c). Shoots from the treatments $0 / 0$ to $3 / 0.3$ had significantly lower tissue $P$ concentrations than shoots from $10 / 1$ to $22 / 2.2$ (1-way ANOVA, $\left.F_{12,39}=14.2, p<0.05\right)$. Concentrations of storage $\mathrm{P}$ in $S$. baccularia tissue, which represents the fraction of phosphorus available for growth, also increased with increasing phosphate supply, with a similar kinetic to that of total tissue P (Fig. 1c). Subtraction of the storage $P$ fraction from total $P$ indicates the fraction of structural phosphorus in the tissue, which was on average about $0.06 \%$ of DW. Shoots from the treatments $0 / 0$ to $3 / 0.3$ had significantly lower concentrations of storage $P$ than shoots from $10 / 1$ to $22 / 2.2$ (1-way ANOVA, $\left.F_{12,39}=10.9, \mathrm{p}<0.05\right)$. The critical nutrient concentration for growth of $S$. baccularia, i.e. the concentration of tissue nutrients below which growth is submaximal, was estimated from Fig. 1 for $\mathrm{N}$ as $0.86 \%$ of DW and for P as $0.09 \%$ of DW

The nutrient uptake rates of cultured Sargassum baccularia shoots were quantified after a minimum of $1 \mathrm{wk}$ adaptation to the respective culture conditions, when the algae were in an apparent steady state. The uptake rates followed a saturation curve that fitted the Michaelis-Menten kinetics. The substrate concentrations where uptake is half-maximal $\left(K_{\mathrm{m}}\right)$ were estimated as $4.8 \mu \mathrm{M}$ ammonium and $0.3 \mu \mathrm{M}$ phosphate (Table 1). The maximal uptake rates ( $V_{\text {max }}$ ) were $13 \mu \mathrm{mol}$ ammonium $\mathrm{g}^{-1} \mathrm{DW} \mathrm{h} \mathrm{h}^{-1}$ and $0.4 \mu \mathrm{mol}$ phosphate $\mathrm{g}^{-1} \mathrm{DW} \mathrm{h} \mathrm{h}^{-1}$ (Table 1). From the quotient of the 2 kinetic parameters for both ammonium and phosphate, the initial slopes, $\alpha$, were derived (Table 1). These slopes were later used in the 'mini budget' to calculate uptake rates in low nutrient concentrations (refer to Table 4). To obtain dark uptake rates, 1 set of samples from each culture flask of the first 2 experimental runs was taken at night. The uptake rates were compared to uptake rates in the light from the same flasks. No differences were detectable between ammonium or phosphate uptake in the light or in the dark in these 4 nutrient treatments $(1 / 0.1,5 / 0.5,10 / 1,22 / 2.2$; paired $t$-test for each treatment, $\mathrm{df}=3, \mathrm{p}>0.05$ ).

Table 1. Sargassum baccularia. Kinetic parameters of nutrient uptake rates measured in cultures with constant nutrient supply. Values are calculated according to Wilkinson (1961) with $95 \%$ confidence limits ( $\mathrm{n}=33$ for ammonium, $\mathrm{n}=44$ for phosphate)

\begin{tabular}{|lccc|}
\hline & $K_{\mathrm{m}}(\mu \mathrm{M})$ & $V_{\max }\left(\mu \mathrm{mol} \mathrm{g} \mathrm{g}^{-1} \mathrm{DW} \mathrm{h}^{-1}\right)$ & $\alpha$ \\
\hline Ammonium & $4.81( \pm 1.08)$ & $13.02( \pm 1.64)$ & 2.7 \\
Phosphate & $0.26( \pm 0.12)$ & $0.43( \pm 0.20)$ & 1.7 \\
\hline
\end{tabular}




\section{Starvation culture}

In nutrient-limiting conditions, growth of Sargassum baccularia shoots first decreased, then ceased after about $15 \mathrm{~d}$ (Fig. 2). This time span indicates the nutrient storage capacity of $S$. baccularia. From Days 20 to 30. growth rates were negative, due to loss of leaf material. Tissue $\mathrm{N}$ and $\mathrm{P}$ concentrations decreased continuously for $15 \mathrm{~d}$ until minimal levels were reached $10.58 \pm 0.06 \% \mathrm{~N}$ of DW and $0.05 \pm 0.004 \% \mathrm{P}$ of DW), which were then sustained for the duration of the experiment (Fig. 2). The subsistence concentrations of $\mathrm{N}$ and $\mathrm{P}$ in $\mathrm{S}$. baccularia tissue at zero growth were estimated from Fig. 2 as $0.6 \% \mathrm{~N}$ of DW and $0.06 \% \mathrm{P}$ of $\mathrm{DW}$. The subsistence concentration of $\mathrm{P}$ is similar to that of structural P in $S$. baccularia tissue calculated in the continuous supply experiments.

\section{Tissue nutrients of field plants}

Tissue N values of Sargassum baccularia were variable during the sampling period at all 3 study locations (Fig. $3 a-c$ ). A distinct seasonal trend was obvious only at

Table 2. Sargassum baccularia. Two-factor ANOVA comparing tissue nitrogen or tissue phosphorus levels in samples from the 3 sampling locations. Factors were tissue type (basal vs distal) and sampling month. Dependent variables were log-transformed and fulfilled the Cochran test of homogeneity of variances

\begin{tabular}{|c|c|c|c|c|c|}
\hline $\begin{array}{l}\text { Depend. } \\
\text { variable }\end{array}$ & Location & $\begin{array}{l}\text { Source } \\
\text { of variation }\end{array}$ & $\mathrm{df}$ & $F$ & $\mathrm{p}$ \\
\hline \multirow[t]{12}{*}{ Tissue N } & \multirow[t]{4}{*}{ Brook Island } & Month & 12 & 17.2 & 0.0001 \\
\hline & & Tissue & 1 & 53.8 & 0.0001 \\
\hline & & Month $\times$ Tissue & 8 & 1.5 & 0.154 \\
\hline & & Error & 86 & & \\
\hline & \multirow[t]{4}{*}{ Great Palm Island } & Month & 12 & 7.8 & 0.0001 \\
\hline & & Tissue & 1 & 34.7 & 0.0001 \\
\hline & & Month $\times$ Tissue & 7 & 1.0 & 0.430 \\
\hline & & Error & 78 & & \\
\hline & \multirow[t]{4}{*}{ Fantome Island } & Month & 11 & 11.2 & 0.0001 \\
\hline & & Tissue & 1 & 71.9 & 0.0001 \\
\hline & & Month $\times$ Tissue & 5 & 2.0 & 0.097 \\
\hline & & Error & 63 & & \\
\hline \multirow[t]{12}{*}{ Tissue P } & \multirow[t]{4}{*}{ Brook Island } & Month & 12 & 12.9 & 0.0001 \\
\hline & & Tissue & 1 & 7.1 & 0.0092 \\
\hline & & Month $\times$ Tissue & 8 & 4.2 & 0.0003 \\
\hline & & Error & 86 & & \\
\hline & \multirow[t]{4}{*}{ Great Palm Island } & Month & 12 & 8.4 & 0.0001 \\
\hline & & Tissue & 1 & 60.7 & 0.0001 \\
\hline & & Month $\times$ Tissue & 7 & 4.1 & 0.0008 \\
\hline & & Error & 78 & & \\
\hline & \multirow[t]{4}{*}{ Fantome Island } & Month & 11 & 10.0 & 0.0001 \\
\hline & & Tissue & 1 & 5.4 & 0.023 \\
\hline & & Month $\times$ Tissue & 5 & 4.0 & 0.003 \\
\hline & & Error & 63 & & \\
\hline
\end{tabular}

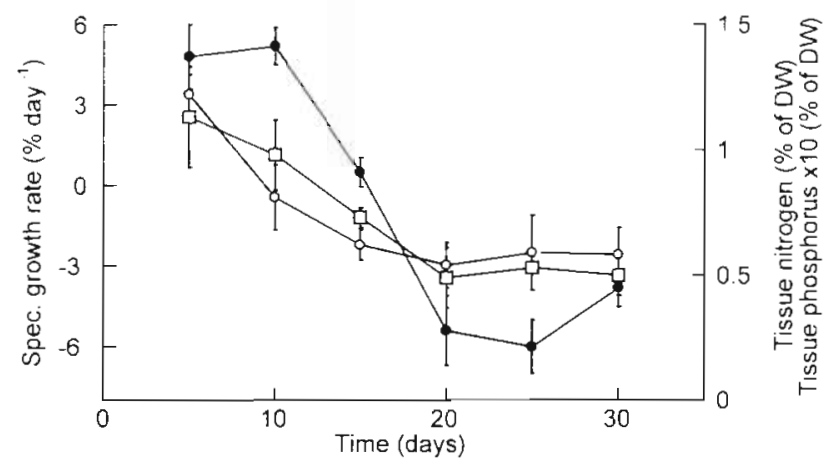

Fig. 2. Sargassum baccularia. Growth and nutrient status in culture in medium without detectable inorganic nutrients. Data are means with $95 \%$ confidence intervals and indicate mass-specific growth rates $(\bullet, n=5)$, total tissue nitrogen $(0$, $\mathrm{n}=3$ ) and total tissue phosphorus $(0, \mathrm{n}=3)$

Brook Islands, where significantly lower tissue $\mathrm{N}$ values occurred in spring (October to December 1995) compared to all other sampling times (Fig. 3a, Table 2). At Great Palm and Fantome Islands a distinct seasonal trend was not obvious $(\mathrm{Fig} .3 \mathrm{~b}, \mathrm{cj}$. Fieduminamity in spring and/or in autumn there were, however, separate sampling months with significantly lower tissue $\mathrm{N}$ levels (Fig. $3 \mathrm{~b}, \mathrm{c}$, Table 2). At our study sites, the beginning of the annual growth phase of $S$. baccularia was in spring and senescence of distal shoots occurred in autumn. During the winter months, long shoots bearing vesicles were not present on the field thalli (distal tissue; Fig. $3 a-c)$; the plants 'overwintered' with slow-growing basal shoots. At all 3 locations, the nitrogen content in the samples taken from basal tissue was significantly higher than in the samples from distal tissue (Fig. 3a-c, Table 2).

For tissue $\mathrm{P}$ the 2-factor ANOVA detected differences between tissue types and sampling time at each of the 3 locations (Table 2). Due to significant interaction terms between the factors time and tissue type (Table 2), a subsequent 1-factor ANOVA was run with all time/tissue type combinations as the factor. For each of the sites, the ANOVA detected significant differences between the time/tissue type combinations (1-way ANOVA: Brook Islands, $F_{21,86}=9.29, \mathrm{p}<0.05$ Great Palm Island, $F_{20,78}=9.43, \mathrm{p}<$ 0.05 ; Fantome Island, $F_{17,63}=6.61, p<$ $0.05)$. The results of the subsequent 

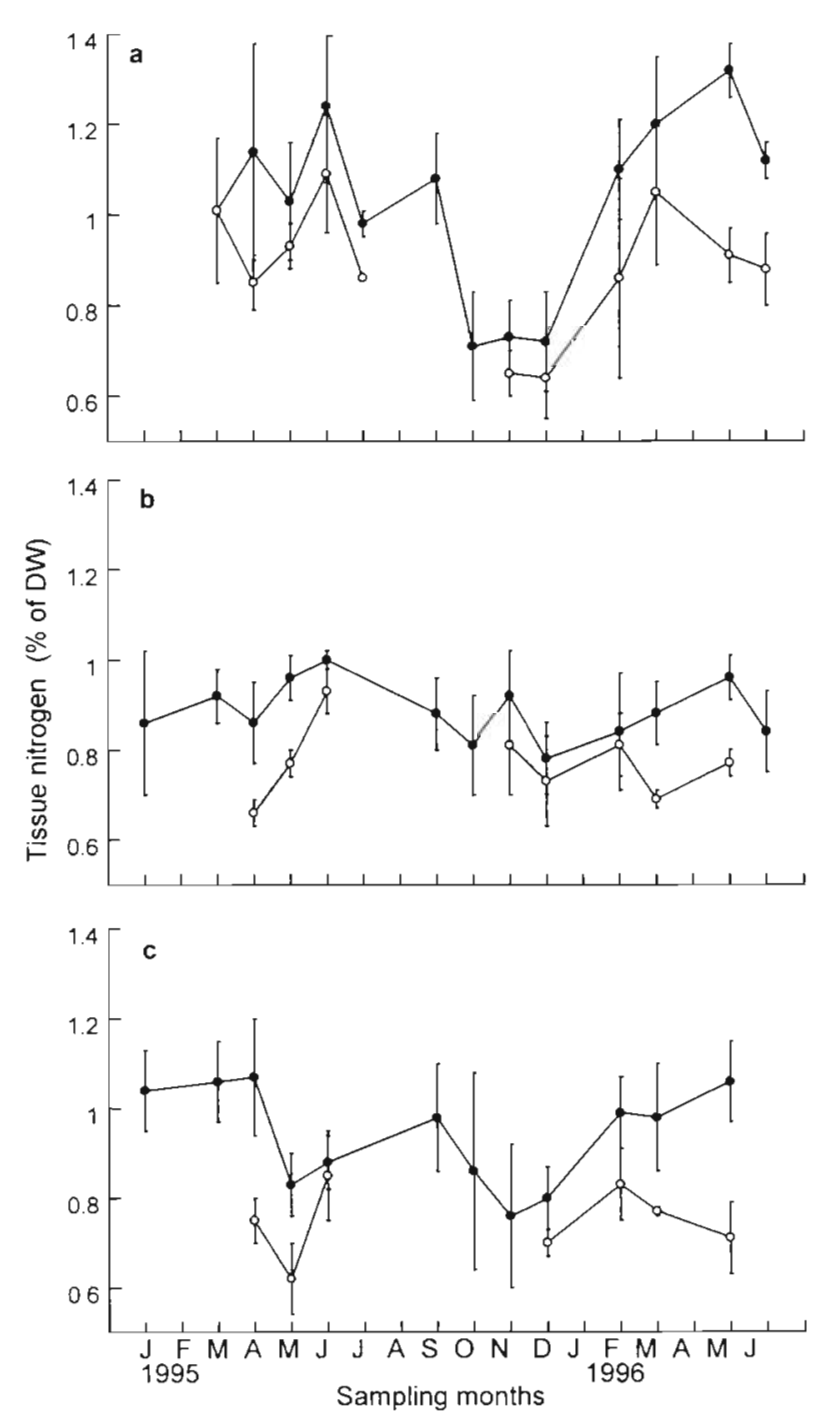

Fig. 3. Sargassum baccularia. Total tissue nitrogen at (a) Brook Islands, (b) Great Palm Island and (c) Fantome Island. Data are means $(n=5)$ with $95 \%$ confidence limits. (•) Young, basal thallus parts; (O) older, distal thallus parts

Tukey-Kramer post hoc tests are not reported in detail, only the relevant effects are presented. At Brook Islands, the samples from November 1995 to February 1996 (summer) had significantly lower tissue P levels than those from all other months (Fig. 4a). Significant differences between the tissue $P$ levels in basal and distal tissue were detected in only 3 of 10 months. In February and March 1996, the distal tissue had lower values than the basal tissue, in June 1996 the reverse was the case (Fig. 4a). At Great Palm and Fantome Islands, no distinct seasonal trends of tissue P concentrations were obvious (Fig. 4 b, c). At Great Palm Island, the distal tissue samples of 5 out of 8 months had significantly lower $P$ levels compared to basal tissue samples (Fig. 4b), whereas at Fantome Island significantly

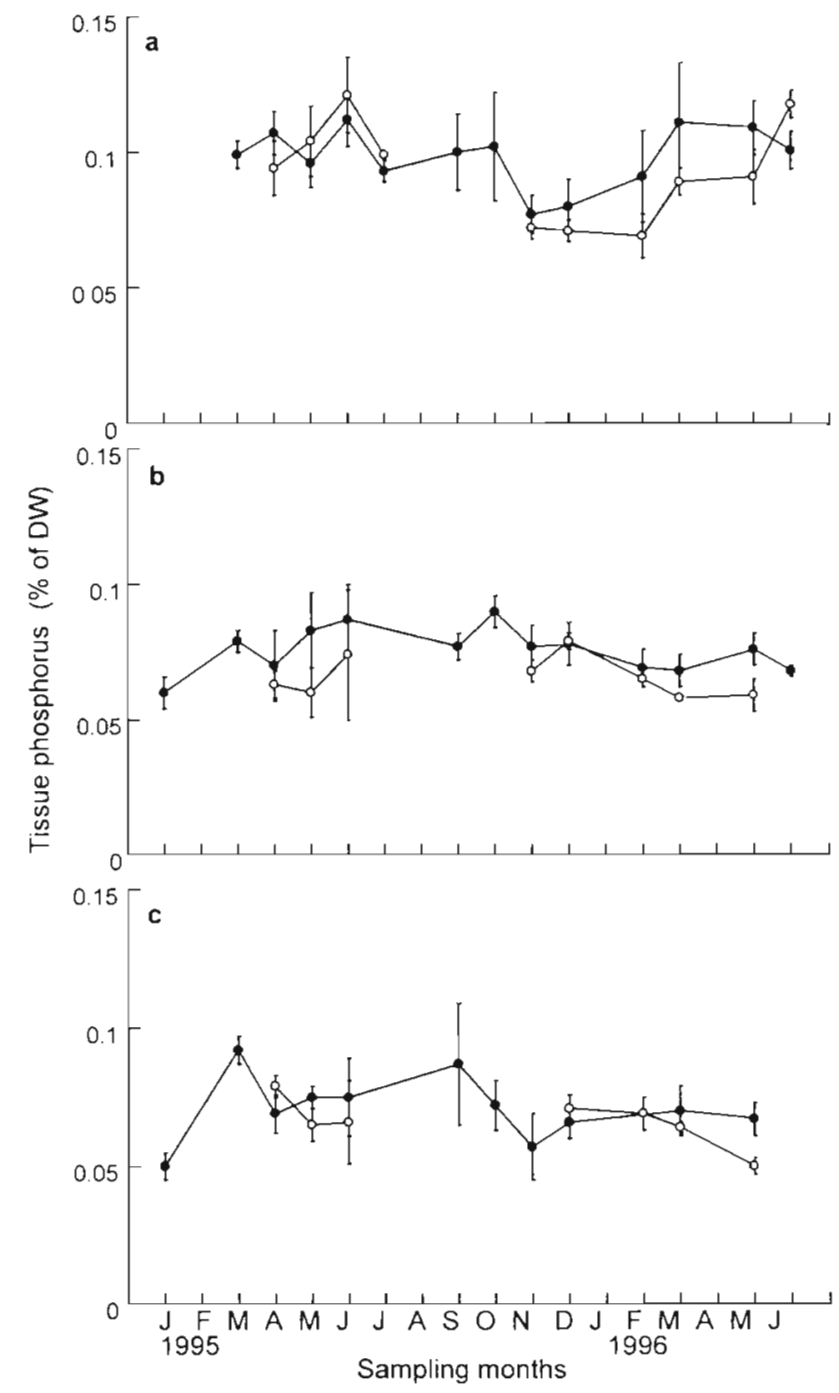

Fig. 4. Sargassum baccularia. Total tissue phosphorus at (a) Brook Islands, (b) Great Palm Island and (c) Fantome Island. Data are means $(n=5)$ with $95 \%$ confidence limits.

( ) Young, basal thallus parts; (o) older, distal thallus parts

lower tissue P levels in distal tissue occurred only in samples from May 1996.

\section{Assessment of nutrient limitation and nutrient budget}

To assess whether Sargassum baccularia at the 3 sampling locations was nutrient-limited or nutrientsufficient, we compared the tissue nutrient data of field algae with the estimated tissue nutrient parameters 'critical nutrient concentration' and 'subsistence nutrient concentration'. We compared the monthly average values as well as the corresponding replicate samples of tissue $\mathrm{N}$ and $\mathrm{P}$ of field thalli with the respective esti- 
Table 3. Sargassum baccularia. Comparison of tissue nutrient concentrations in field thalli with critical or subsistence nutrient levels estimated in laboratory experiments (according to Hanisak 1979 for critical levels and Fujita et al. 1989 for subsistence levels]. Data are the percentage of tissue samples that fell below the respective parameter

\begin{tabular}{|c|c|c|c|c|}
\hline & $\begin{array}{c}\text { Critical N } \\
(0.86 \% \text { of DW })\end{array}$ & $\begin{array}{l}\text { Subsistence } N \\
(0.6 \% \text { of DW) }\end{array}$ & $\begin{array}{c}\text { Cntical P } \\
(0.09 \% \text { of DW })\end{array}$ & $\begin{array}{l}\text { Subsistence } P \\
(0.06 \% \text { of } \mathrm{DW})\end{array}$ \\
\hline \multicolumn{5}{|l|}{ Brook Island } \\
\hline Single samples $(n=108)$ & 37 & 4 & 35 & 1. \\
\hline Averages, distal tissue $(n=11)$ & 64 & 0 & 45 & 0 \\
\hline Averages, basal tissue $(n=13)$ & 23 & 0 & 15 & 0 \\
\hline \multicolumn{5}{|l|}{ Great Palm Island } \\
\hline Single samples $(n=99)$ & 67 & 1 & 92 & 16 \\
\hline Averages, distal tissue $(n=8)$ & 100 & 0 & 100 & 25 \\
\hline Averages, basal tissue $(n=13)$ & 54 & 0 & 100 & 8 \\
\hline \multicolumn{5}{|l|}{ Fantome Island } \\
\hline Single samples $(n=89)$ & 58 & 1 & 91 & 19 \\
\hline Averages, distal tissue $(n=7)$ & 100 & 0 & 100 & 14 \\
\hline Averages, basal tissue $(n=12)$ & 42 & 0 & 100 & 17 \\
\hline
\end{tabular}

mated parameters. At Brook Islands about one-third of the replicate samples were below the critical $N$ content (Table 3), estimated to be $0.86 \%$ of DW. Separated by tissue type, $23 \%$ of the monthly averages of basai tissue and $64 \%$ of the averages of distal tissue were below the critical $N$ content (Table 3). At Great Palm and Fantome Islands, more than half the replicate samples, about half of the monthly averages of basal tissue, and $100 \%$ of the monthly averages of distal tissue were below this critical value (Table 3 ). At all locations, $S$. baccularia thalli with average tissue $\mathrm{N}$ concentrations below the critical $\mathrm{N}$ level were found particularly during summer and autumn months (cf. Fig. $3 a-c$ ). In contrast, the tissue $\mathrm{N}$ concentrations of only a very small number of the replicate samples and none of the monthly average values fell below the subsistence nitrogen concentration, estimated to be $0.6 \%$ of $\mathrm{DW}$ (Tabie 3).

Tissue $\mathrm{P}$ levels were below the critical $\mathrm{P}$ concentration $(0.09 \%$ of DW) in $35 \%$ of the replicate samples from Brook Islands (Table 3). Separated by tissue type, about half of the monthly averages of the distal and $15 \%$ of the basal tissue samples from Brook Islands were below this critical value (Table 3). Again, especially during summer months, tissue $\mathrm{P}$ concentrations were below the critical P level (cf. Fig 4a). More than $90 \%$ of the replicate samples and all monthly average values from Great Palm and Fantome Islands were

Table 4. Sargassum baccularia. Estimated nitrogen (N) and phosphorus (P) budget for the in situ growth at Great Palm Island. Nutrient demands were estimated with the in situ growth rates and the corresponding tissue nutrient levels of field plants (cf. Figs. 3 \& 4). Nutrient supply was calculated from the water column concentrations of DIN (ammonium, nitrate, nitrite) and phosphate and the respective initial slopes $\alpha$ of the Michaelis-Menten kinetics (ct. Table 1). Data are means of $n=10$ (growth rates) or $\mathrm{n}=9$ (water column nutrients) with $95 \%$ confidence intervals. Symbols are qualifiers that represent months in which the nutrient demand exceeded the supply $(-)$, the supply exceeded the demand $(+)$, or demand and supply were balanced $( \pm$, less than $10 \%$ difference)

\begin{tabular}{|c|c|c|c|c|c|c|c|c|c|}
\hline Time & $\begin{array}{c}\text { Specific growth } \\
\text { rate } \\
\left(\% d^{-1}\right)\end{array}$ & 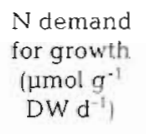 & $\begin{array}{c}\text { Water } \\
\text { column DIN } \\
(\mu \mathrm{M})\end{array}$ & $\begin{array}{l}\text { N supplied by } \\
\text { DIN uptake } \\
\left(\mu \mathrm{mol} \mathrm{g} \mathrm{g}^{-1}\right. \\
\text { DW d d-1 }\end{array}$ & $\begin{array}{l}N \text { supply } \\
\text { vs demand }\end{array}$ & $\begin{array}{l}\text { P demand } \\
\text { for growth } \\
\text { (umol } g^{-1} \\
\text { DW d d }\end{array}$ & $\begin{array}{l}\text { Water } \\
\text { column } \\
\mathrm{PO}_{4} \\
(\mu \mathrm{M})\end{array}$ & $\begin{array}{l}\text { P supplied by } \\
\mathrm{PO}_{4} \text { uptake } \\
\left(\mu \mathrm{mol} \mathrm{g}^{-1}\right. \\
\left.\mathrm{DW} \mathrm{d}^{-1}\right)\end{array}$ & $\begin{array}{l}\text { P supply } \\
\text { vs demand }\end{array}$ \\
\hline Jun 1995 & $0.82( \pm 0.22)$ & 5.7 & $0.53( \pm 0.23)$ & 34.3 & + & 0.23 & $0.05( \pm 0.05)$ & 2.04 & + \\
\hline Aug 1995 & $0.42( \pm 0.15)$ & $2.9^{\circ}$ & $0.04( \pm 0.05)$ & 2.6 & \pm & $0.10^{\mathrm{d}}$ & $0.01( \pm 0.01)$ & 0.41 & + \\
\hline Oct 1995 & $1.43( \pm 0.52)$ & 7.9 & $0.51( \pm 0.26\}$ & 33.0 & + & 0.42 & $0.03( \pm 0.02)$ & 1.22 & + \\
\hline Dec 1995 & $2.71 .( \pm 0.76)$ & 15.0 & $0.18( \pm 0.07)$ & 11.7 & - & 0.68 & $0.01( \pm 0.01)$ & 0.41 & - \\
\hline Feb 1996 & $2.51( \pm 0.49)$ & 15.0 & $0.06( \pm 0.02)$ & 3.9 & - & 0.55 & $0.01( \pm 0.01)$ & 0.41 & - \\
\hline Mar 1996 & $2.41( \pm 0.68)$ & 15.0 & $0.25( \pm 0.10)$ & 16.2 & \pm & 0.52 & $0.01( \pm 0.01)$ & 0.41 & - \\
\hline May 1996 & $1.80( \pm 0.41)$ & 12.1 & $0.46( \pm 0.16)$ & 28.8 & + & 0.45 & $0.01( \pm 0.00)$ & 0.41 & \pm \\
\hline Jun 1996 & $1.15( \pm 0.29)$ & 8.6 & $0.58( \pm 0.14)$ & 37.6 & + & 0.26 & $0.05( \pm 0.02)$ & 2.04 & + \\
\hline
\end{tabular}


below the critical P level (Table 3). At Brook Jslands only a few replicate samples fell below the subsistence $\mathrm{P}$ concentration, which was estimated to be $0.06 \%$ of DW (Table 3). At Great Palm and Fantome Islands, about $20 \%$ of the monthly average values were below the subsistence concentration (Table 3). At Great Palm Island, there were more distal than basal tissue samples with $\mathrm{P}$ concentrations below this value (Table 3 ).

As a second approach to assess the possibility of nutrient limitation of field Sargassum baccularia, we assembled a 'mini budget' with the data available. In this simplified nutrient budget we contrasted estimates of the nutrient requirements for the growth of $S$. baccularia with the estimated nutrient supply in the field (Table 4). The growth rates of $S$. baccularia thalli were high between October and May with distinct maxima from December to March (Table 4). Accordingly, the estimated nutrient requirements for these growth rates were higher in austral summer than in winter (Table 4). The concentrations of DIN in the water column at Great Palm Island ranged from $0.04 \mu \mathrm{M}$ (most replicates below the detection limits) to $0.58 \mu \mathrm{M}$, with an average of $0.33( \pm 0.11) \mu \mathrm{M}$. Water column inorganic phosphate had an average concentration of 0.02 $( \pm 0.01) \mu \mathrm{M}$ with a range of $0.01 \mu \mathrm{M}$ (most replicates below the detection limit) to $0.05 \mu \mathrm{M}$. Estimates of the potential nutrient uptake from the water column indicate that nutrient limitation may occur during the summer period of most rapid growth. In December and February the estimated $\mathrm{N}$ uptake is smaller than the estimated $\mathrm{N}$ demand for growth, in March supply and demand are about balanced, and in all other months the $N$ supply exceeds the demand (Table 4). The P demand is not met by $\mathrm{P}$ uptake from December to March, in May demand and supply are balanced, and in all other months the P supply exceeds the demand (Table 4).

\section{DISCUSSION}

Results from the present study indicate that the growth of Sargassum baccularia is nutrient limited at the 3 study locations. However, this species is highly abundant on reef flats of nearshore island-fringing reefs of the GBR (Schaffelke \& Klumpp 1997a), indicating that the abiotic and biotic conditions on these sites are already suitable for macroalgal growth. The observed high biomass of Sargassum species and other fleshy macroalgae has raised the concern that this may indicate degradation of nearshore coral reefs involving a phase shift from coral to algal dominance (Done 1992, McCook et al. 1997). Nearshore reefs will continue to be subjected to inputs of nutrients and particulates from mainland run-off. We suggest that in mod- erately enhanced nutrient conditions (concentrations of 3 to $5 \mu \mathrm{M}$ ammonium and 0.3 to $0.5 \mu \mathrm{M}$ phosphate) Sargassum species may become nutrient-sufficient. If enhanced nutrient concentrations were paired with sufficient available substrata and a low grazing pressure, Sargassum species would have the potential to colonise larger areas on the nearshore reefs.

In laboratory experiments we promoted the growth of Sargassum baccularia by continuous, moderate nutrient enhancements ( 3 to $5 \mu \mathrm{M}$ ammonium, 0.3 to $0.5 \mu \mathrm{M}$ phosphate). Ammonium and phosphate were supplied together because we attempted to simulate an increased nutrient input in the field, caused for example by increased run-off of agricultural fertiliser, which consists of both $\mathrm{N}$ and $\mathrm{P}$ (Brodie 1995). Other experiments indicate an additive effect of $\mathrm{N}$ and $\mathrm{P}$ on growth of $S$. baccularia such that the application of $N$ and $P$ combined has a larger effect than additions of any one element (authors' unpubl. data). The growth of early life history stages of $S$. baccularia is also promoted by experimental nutrient additions: germlings and juvenile thalli grew significantly faster in low and moderate $\mathrm{N}$ and $\mathrm{P}$ enrichments $(0.8$ or $8 \mu \mathrm{M}$ ammonium/0.1 or $1 \mu \mathrm{M}$ phosphate) than controls in nonenriched seawater (Schaffelke \& Klumpp 1997b). In the present study we could not apply the models of Monod (1942) and Droop (1974) to characterise our growth versus nutrient substrate kinetics, because the growth followed a distinct optimum curve and not a saturable hyperbolic function as required for these models. The reason why the growth of $S$. baccularia was inhibited at higher nutrient concentrations remains obscure. At high concentrations, the algae were actively taking up nutrients and accumulating saturated tissue nutrient stores. The growth inhibition seems to be a direct effect of the high nutrient concentrations in the growth medium since in other experiments $S$. baccularia shoots with saturated tissue nutrients show increased growth promotion when incubated in non-enriched seawater (authors' unpubl. data). Toxic effects of ammonium addition have been observed after very high additions, ranging from ca $50 \mu \mathrm{M}$ to millimolar concentrations (Waite \& Mitchell 1972, McLachlan 1977, Ogawa 1984).

To extrapolate from the nutrient concentrations that allowed maximum growth in the culture experiments to the nutrient concentrations in the field, it may be more meaningful to relate growth to the actual nutrient concentrations in the culture flasks, i.e. after nutrient uptake. Because ammonium and phosphate uptake was only measured at 3 occasions per experimental run, we can only estimate the actual culture concentrations. According to this estimation, the maximum growth rates were attained at 2 to $4 \mu \mathrm{M}$ ammonium and 0.25 to $0.45 \mu \mathrm{M}$ phosphate. These nutrient concen- 
trations were within, or slightly above, the range of inorganic nutrient concentrations from locations where abundant macroalgae colonise reef areas (Smith et al. 1981, Cuet et al. 1988, Lapointe 1989). We suggest that Sargassum species are indicators of moderately enhanced nutrient conditions, in which they display maximum growth. However, the ammonium and phosphate concentrations that enabled $S$. baccularia to grow maximally were never measured at our study sites. The nutrient concentrations where growth was half maximal were 0.5 to $1 \mu \mathrm{M}$ ammonium and 0.05 to $0.1 \mu \mathrm{M}$ phosphate (estimated concentrations in the culture medium: 0.25 to $0.5 \mu \mathrm{M}$ ammonium and 0.04 to $0.07 \mu \mathrm{M}$ phosphate), which is in the upper range of nutrient concentrations measured in the water column at the field sites. Nutrient concentrations in the water column at our study sites were very variable. In general, DIN concentrations were below $1 \mu \mathrm{M}$ and phosphate concentrations below $0.1 \mu \mathrm{M}$, and about half the samples had undetectable ammonium and phosphate levels (this paper, Klumpp et al. in press, S. Uthicke, B. Schaffelke \& D. W. Klumpp unpubl. data). The concentrations of $1 \mu \mathrm{M}$ DIN and $0.1 \mu \mathrm{M}$ phosphate represent estimated threshhold concentrations above which macroalgal blooms were observed on coral reefs (Bell 1992, Lapointe et al. 1993, 1997). Water column nutrients in open waters in the GBR lagoon are generally low and often at the limit of detection (Furnas et al. 1995). Fluxes of nutrients on coral reefs are not well understood, but it is assumed that free inorganic nutrients are rapidly incorporated by phytoplankton and benthic biomass, leaving very little measurable nutrients in the water column. To assess whether the Sargassum canopy may affect the water column nutrients, we conducted measurements of dissolved nutrients inside and outside Sargassum beds, but did not find a significant difference (B. Schaffelke unpubl. data). In contrast, Schramm et al. (1988) measured higher nutrient concentrations inside temperate algal beds than in surface water.

In our study, nutrient uptake rates were measured in the continuous supply experiments, thus avoiding the problems associated with the interpretation of uptake rates obtained by batch-mode experiments (Harrison et al. 1989) and providing ecologically more meaningful data (Probyn \& Chapman 1982). Generally, the kinetic parameters $K_{\mathrm{m}}$ and $V_{\max }$ for ammonium and phosphate uptake by Sargassum baccularia are in the range reported for other brown algae (see Wallentinus 1984). Comparisons between species have to be viewed with caution, because the methods and conditions under which the uptake was measured may be very different between studies (Harrison et al. 1989). In our study, the substrate concentrations at which uptake rates of ammonium or phosphate, respectively, were half-maximal $\left(K_{\mathrm{m}}\right)$ are about 10 times higher than the average concentrations of DIN or phosphate in the water column at the field site (about $0.3 \mu \mathrm{M}$ DIN, $0.02 \mu \mathrm{M}$ phosphate). This may indicate that uptake at low field concentrations may not be very efficient, assuming that nutrient concentrations remain at the measured low levels and no nutrient spikes occur. The nutrient situation in the field, however, is likely to be very variable, especially during the summer wet season, when rivers import nutrients into the coastal zone.

We are aware that the nutrient concentrations without consideration of the nutrient flux (or loading) give only an insufficient description of the nutrient situation at a field site, i.e. low nutrient concentrations may be sufficient to supply macroalgal growth when the flow rate is high (Larned \& Stimson 1996). The present laboratory data were obtained in continuous flow experiments, which offered a relatively constant nutrient supply over time, although the flow is likely to be lower than in the field. To extrapolate from the laboratory situation, we decided not to rely on 'snapshot' flow measurements in situ, but to use the uptake rates and tissue nutrient levels obtained in the continuous flow cultures to estimate the nutrient supply of Sargassum baccularia in the field.

The nutrient content in algal tissue has long been recognised as a transient nutrient store in environments with periodic nutrient supply, as well as both an integrator for the nutritional history of the plants and a bioindicator for water quality (Rosenberg \& Ramus 1982, Björnsäter \& Wheeler 1990, Lyngby 1990, Lapointe et al. 1992, Fong et al. 1994, Jones et al. 1996). To evaluate the nutrient supply and potential nutrient limitation of field Sargassum baccularia, we compared the estimated critical and subsistence levels of tissue $\mathrm{N}$ and $\mathrm{P}$ with the respective field tissue nutrient data. This comparison showed that $S$. baccularia was always sufficiently supplied with $\mathrm{N}$ and $\mathrm{P}$ to show positive growth rates (almost all tissue data were above the subsistence level of both elements). Particularly in austral summer, which is the period of fast growth of S. baccularia (Schaffelke \& Klumpp 1997a), both tissue $\mathrm{N}$ and $\mathrm{P}$ concentrations of field thalli fell below the respective critical nutrient values. Both $N$ and $\mathrm{P}$ limitation appeared to be less pronounced at Brook Islands than at the other 2 sites. At Great Palm and Fantome Islands, $P$ limitation was more distinct than $\mathrm{N}$ limitation, indicated by the fact that almost all samples were below the critical phosphorus level. Hence, especially in summer, any extra nutrient supply, $\mathrm{N}$ and/or $\mathrm{P}$, may lead to enhanced growth of $S$. baccularia. The estimated subsistence level for $\mathrm{P}$ of $0.06 \%$ of DW equals the proportion of structural $P$ that we calculated from tissue P data in the continuous supply experiments. This indicates that in starvation con- 
ditions all storage $P$ has been exhausted. The subsistence $P$ concentration subtracted from the critical $P$ concentration of $0.09 \%$ of DW would yield a physiological P pool of about $0.03 \%$ of DW; tissue P fractions above the critical level are luxury $P$ stores (adapted from Hanisak 1983). We could not achieve a meaningful measure of storage $N$, probably because of the use of dried tissue material. Studies addressing soluble fractions of tissue $N$, i.e. the physiological and the storage $N$ pool (after Hanisak 1983), generally used fresh tissue material (Thomas et al. 1987).

As a second tool to evaluate the nutrient limitation of Sargassum baccularia in the field, we calculated a nutrient 'mini budget' with the available laboratory and field data. Especially during summer months, the nutrient demand of $S$. baccularia was high because of the very high growth rates in that season (Schaffelke \& Klumpp 1997a, this paper). In these months the nutrient demand was not met by the nutrient supply through uptake of dissolved inorganic nutrients. Only during the period of slow growth in autumn and winter was there less nutrient demand and the uptake of inorganic nutrients delivered a more than sufficient supply for $S$. baccularia thalli. In conjunction with the finding that the tissue nutrient values during the summer months were below the critical limits, this budget corroborates the conclusion that maximum possible growth at Great Palm Island was not attained because of nutrient limitation.

At the field sites we measured maximum growth rates of $3 \%$ (Schaffelke \& Klumpp 1997a, this paper). These are net growth rates, including tissue losses due to grazing, erosion, etc. Carbon-specific net production of field Sargassum baccularia has been reported as maximal 9\% $\mathrm{d}^{-1}$ (Schaffelke \& Klumpp 1997a). It is thus very likely that the nutrient demand of field thalli is even higher to account for tissue losses. In the experiments we measured ammonium uptake only, and for the calculation of total DIN uptake in the budget we assumed similar uptake rates for ammonium and nitrate. Our calculated nutrient supply may be overestimated, because nitrate and nitrite uptake are light dependent and often lower in the dark (D'Elia \& DeBoer 1978, Hanisak \& Harlin 1978). The nutrient limitation in the field may hence be even more pronounced than that assessed in the nutrient budget.

Nutrients are imported to the GBR predominantly by diffuse sources such as rain, riverine input and natural upwelling (Furnas et al. 1995, Furnas \& Mitchell 1997). Riverine input is the major nutrient source (Mitchell \& Furnas 1997), carrying land run-off enriched with agricultural fertiliser (Brodie 1995). Especially during the summer wet season, the period of fast growth of Sargassum baccularia, nutrients are imported via rain and riverine input (Furnas et al. 1995). These episodic enrichment events are likely to be missed by standard sampling programs, but may be important nutrient sources for the summer growth of macroalgae when nutrient demand is high. If land-derived nutrient imports increased, these nutrients would be highly effective in summer, when river plumes may reach as far as to the nearshore reefs (Brodie 1997) and when the Sargassum species are most nutrient-limited and hence, most responsive.

Acknowledgements. We thank Eric Bunn from the Palm Island Ranger Service and the Queensland Dept of Environment and Heritage for permits to work on the reefs of the Palm and Brook Islands, respectively. The support of the masters and crews of the AIMS research vessels is greatly appreciated. Special thanks go to Stephen Boyle for invaluable help with the $\mathrm{C} / \mathrm{N}$ analyser and to Daryl Birkett for advise on tissue $P$ methods. The constructive criticism of Sven Uthicke and the 3 referees greatly improved this manuscript. The work was made possible by a research fellowship of the Deutsche Forschungsgemeinschaft to B.S. This is publication no. 910 from the Australian Institute of Marine Science.

\section{LITERATURE CITED}

Bell PRF (1991) Status of eutrophication in the Great Barrier Reef lagoon. Mar Pollut Bull 23:89-93

Bell PRF (1992) Eutrophication and coral reefs-some examples in the Great Barrier Reef lagoon. Wat Res 26:553-568

Bell PRF, Elmetri I (1995) Ecological indicators of large-scale eutrophication in the Great Barrier Reef lagoon. Ambio 24: $208-215$

Björnsäter BR, Wheeler PA (1990) Effect of nitrogen and phosphorus supply on growth and tissue composition of Ulva fenestrata and Enteromorpha intestinalis (Ulvales, Chlorophyta). J Phycol 26:603-611

Brodie JE (1995) The problem of nutrients and eutrophication in the Australian marine environment. In: Zann L, Sutton $D$ (eds) State of the Marine Environment Report for Australia, Pollution, Technical Annex: 2. Department of Environment, Sport and Territories, Canberra ACT

Brodie JE (1997) The water quality status of the Great Barrier Reef World Heritage Area. In: Wachenfeld D, Oliver J, Davis K (eds) State of the Great Barrier Reef World Heritage Area Workshop. Workshop Series No. 23, Great Barrier Reef Marine Park Authority, Townsville

Brodie JE, Furnas MJ, Steven ADL, Trott LA, Pantus F, Wright $M$ (1997) Monitoring chlorophyll in the Great Barrier Reef lagoon: trends and variability. Proc 8th Coral Reef Symp 1: $797-802$

Chopin T, Hourmant A, Floc'h JY, Penot M (1990) Seasonal variations of growth in the red alga Chondrus crispus on the Atlantic French coasts. II. Relations with phosphorus concentration in seawater and internal phosphorylated fractions. Can J Bot 68:512-517

Crossland CJ, Barnes DJ (1983) Dissolved nutrient and organic particles in water flowing over coral reefs at Lizard Islands. Aust J Mar Freshwat Res 34:835-844

Crossland CJ, Hatcher BG, Atkinson MJ, Smith SV (1984) Dissolved nutrients of a high latitude coral reef, Houtman Abrolhos Islands, Western Australia. Mar Ecol Prog Ser $14: 159-163$

Cuet P, Naim O, Faure G, Conan JY (1988) Nutrient-rich groundwater impact on benthic communities of La Saline 
fringing reef (Reunion Island, Indian Ocean): preliminary results. Proc 6th Int Coral Reef Symp 2:207-212

D'Elia CF, DeBoer JA (1978) Nutritional studies of two red algae. II. Kinetics of ammonium and nitrate uptake. J Phy$\operatorname{col} 14: 266-272$

Done TJ (1992) Phase shifts in coral communities and their ecological significance. Hydrobiologia 247:121-132

Droop MR (1974) The nutrient status of algal cells in continuous culture. J Mar Biol Assoc UK 54:825-855

Fong P, Donohoe RM, Zedler JB (1994) Nutrient concentration. in tissue of the macroalga Enteromorpha as a function of nutrient history: an experimental evaluation using field microcosms. Mar Ecol Prog Ser 106:273-281

Fujita RM (1985) The role of nitrogen status in regulating transient ammonium uptake and nitrogen storage by macroalgae. J Exp Mar Biol Ecol 99:283-301

Fujita RM, Wheeler PA, Edwards RL (1989) Assessment of macroalgal nutrient limitation in a seasonal upwelling region. Mar Ecol Prog Ser 53:293-303

Furnas MJ, Mitchell AW (1997) Biological oceanography of the Great Barrier Reef. In: The Great Barrier Reef, Science, Use and Management. A National Conference: Proceedings Vol 1 Great Barrier Reef Marine Park Authority, Townsville, p 75-87

Furnas MJ, Mitchell AW, Skuza M (1995) Nitrogen and phosphorus budget for the Central Great Barrier Reef Shelf. Research Publication No. 36, Great Barrier Reef Marine Fark Áuthority, Townsville

Hanisak MD (1979) Nitrogen limitation of Codium fragile ssp. tomentosoides as determined by tissue analysis. Mar Biol 50:333-337

Hanisak MD (1983) The nitrogen relationships of marine macroalgae. In: Carpenter EJ, Capone DG (eds) Nitrogen in the marine environment. Academic Press, New York, p $699-730$

Hanisak MD, Harlin MM (1978) Uptake of inorganic nitrogen by Codium fragile ssp. tomentosoides (Chlorophyta) J Phycol 14:450-454

Harrison PJ, Parslow JS, Conway HL (1989) Determination of nutrient uptake kinetic parameters: a comparison of methods. Mar Ecol Prog Ser 52:301-312

Hatcher AI, Hatcher BG (1981) Seasonal and spatial variation in dissolved inorganic nitrogen in One Tree Reef lagoon. Proc 4th Int Coral Reef Symp 1:419-424

Hatcher BG (1988) The primary productivity of coral reefs: a beggar's banquet. Trends Ecol Evol 3:106-111

Hatcher BG (1990) Coral reef primary productivity: a hierarchy of patterns and processes. Trends Ecol. Evol 5:149-155

Hatcher BG, Larkum AWD (1983) An experimental analysis of factors controlling the standing crop of the epilithical algal community on a coral reef. J Exp Mar Biol Ecol 69:61-84

Hay ME (1984) Pattern of fish and urchin grazing on Caribbean coral reefs: are previous results typical? Ecology 65:446-454

Healey FP (1980) Slope of the Monod equation as an indicator of advantage in nutrient competition. Microb Ecol 5:281-286

Hughes TP (1994) Catastrophes, phase-shifts and large scale degradation of a Caribbean coral reef. Science 265: $1547-1551$

Jones AB, Dennison WC, Stewart GR (1996) Macroalgal responses to nitrogen source and availability: amino acid profiling as a bioindicator using Gracilaria edulis (Rhodophyta). J Phycol 32:757-766

Klumpp DW, Done TJ, McKinnon AD, Robertson AJ., Brunskill GJ (in press) Response of nearshore reefs to nutrient enhancement Phase I: Baseline information on nutrient concentrations, primary produrtion and reef community structure, Research Publication, Great Barrier Reef Marine Park A.uthority, Townsville

Koroleff F (1983a) Determination of ammonia. In: Grasshoff K, Ehrhardt M, Kremling $\mathrm{K}$ (eds) Methods of seawater analyses. Verlag Chemie, Weinheim, p 150-157

Koroleff $F$ (1983b) Determination of dissolved inorganic phosphate. In: Grasshoff $\mathrm{K}$, Ehrhardt $\mathrm{M}$. Kremling $\mathrm{K}$ (eds) Methods of seawater analyses. Verlag Chemie, Weinheim, p 126-131

Koroleff $F(1983 c)$ Determination of total phosphorus by acid persulphate oxidation. In: Grasshoff $K$, Ehrhardt $M$, Kremling $K$ (eds) Methods of seawater analyses. Verlag Chemie, Weinheim, p 134-136

Lapointe BE (1989) Macroalgal production and nutrient relations in oligotrophic areas of Florida Bay. Bull Mar Sci 44: $312-323$

Lapointe BE, Littler MM, Littler DS (1992) Nutrient availability to marine macroalgae in siliciclastic versus carbonaterich coastal waters. Estuaries 15:75-82

Lapointe BE, Littler MM, Littler DS (1993) Modification of benthic community structure by natural eutrophication: the Belize Barrier Reef Proc 7th Int Coral Reef Symp 1: $323-334$

Lapointe BE, Littler MM, Littler DS (1997) Macroal.gal overgrowth of fringing coral reefs at Discovery Bay, Jamaica: bottom-up versus top-down control. Proc 8th Coral Reef Symp 1:927-932

Lapointe BE. O'Connell J (1989) Nutrient-enhanced growth of Cladophora prolifera in. Harrigton Sound, Bermuda: Eutrophication of a confined phosphorus-limited marine ecosystem. Estuar Coast Shelf Sci 28:347-360

Larned ST, Stimson J (1996) Nitrogen-limited growth in the coral reef chlorophyte Dictyosphaeria cavernosa, and the effect of exposure to sediment-derived nitrogen on growth. Mar Ecol Prog Ser 145:95-108

Littler MM, Littler DS (1.984) Models of tropical reef biogenesis: the contribution of algae. Prog Phycol Res 3:323-364

Lundberg P, Weich RG, Jensen P, Vogel HJ (1989) Phosphorus-31 and nitrogen-14 NMR studies of the uptake of phosphorus and nitrogen compounds in the marine macroalga Ulva lactuca. Plant Physiol 89:1380-1387

Lyngby JE (1990) Monitoring of nutrient availability and limitation using the marine macroalga Ceramium rubrum (Huds.) C. Ag. Aquat Bot 38:153-161

Martin-Smith KM (1993) The phenology of four species of Sargassum at Magnetic Island, Australia. Bot Mar 36: $327-334$

McCook LJ (1996) Effects of herbivores and water quality on the distribution of Sargassum on the central Great Barrier Reef: cross-shelf transplants. Mar Ecol Prog Ser 139: $179-1.92$

McCook LJ (1997) Effects of herbivory on zonation of Sargassum spp. within fringing reefs of the Central Great Barrier Reef. Mar Biol 129:713-722

McCook LJ, Price IR (1997) Macroalgal distributions on the Great Barrier Reef: a review of patterns and causes. In: The Great Barrier Reef, Science, Use and Management. A National Conference: Proceedings Vol 2. Great Barrier Reef Marine Park Authority, Townsville, p 37-46

McCook LJ, Price IR, Klumpp DW (1997) Macroalgae on the GBR: causes or consequences, indicators or models of reef degradation. Proc 8th Int Coral Reef Symp 2:1851-1856

McLachlan J (1977) Effects of nutrients on growth and development of embryos of Fucus edentatus Pyl. (Phaeophyceae, Fucales). Phycologia 16:329-338

Miller MW, Hay ME (1996) Coral-seaweed-grazer-nutrient interactions on temperate reefs. Ecol Monogr 66:323-344 
Mitchell AW, Furnas MJ (1997) Terrestrial inputs of nutrients and suspended sediments to the GBR lagoon. In: The Great Barrier Reef, Science, Use and Management. A National Conference: Proceedings Vol 1. Great Barrier Reef Marine Park Authority, Townsville, p 59-71

Monod J (1942) Recherches sur la croissance des cultures bacteriénnes. Hermann et Cie, Paris

Morrissey J (1980) Community structure and zonation of macroalgae and hermatypic corals on a fringing reef flat of Magnetic Island Queensland, Australia. Aquat Bot 8: 91-139

Moss AJ, Rayment GE, Reilly N, Best EK (1992) A preliminary assessment of sediment and nutrient exports from Queensland coastal catchments. Environment Technical Report No 5, Queensland Department of Environment and Heritage, Brisbane, p 27

Ogawa $\mathrm{H}$ (1984) Effects of treated municipal wastewater on the early development of sargassaceous plants. Hydrobiologia 116/117:389-392

Pastorok RA, Bilyard GB (1985) Effects of sewage pollution on coral-reef communities. Mar Ecol Prog Ser 21:175-189

Probyn TA, Chapman ARO (1982) Nitrogen uptake characteristics of Chordaria flagelliformis (Phaeophyta) in batch mode and continuous mode experiments. Mar Biol 71 : 129-133

Pulsford JS (1996) Historical nutrient usage in coastal Queensland river catchments adjacent to the Great Barrier Reef Marine Park. Research Publication No. 40, Great Barrier Reef Marine Park Authority, Townsville

Rose C, Risk M (1985) Increase in Cliona delitrix infestation of Monastrea cavernosa heads on an organically polluted portion of the Grand Cayman fringing reef. Mar Ecol Prog Ser 6:345-363

Rosenberg G, Ramus J (1982) Ecological growth strategies in the seaweed Gracilaria foliifera (Rhodophyceae) and Ulva sp. (Chlorophyceae): soluble nitrogen and reserve carbohydrates. Mar Biol 66:251-259

Ryle VD, Mueller HR, Gentien P (1981) Automated analysis of nutrients in tropical sea waters. AIMS Technical Bulletin, Oceanography Series No. 3, Australian Institute of Marine Science, Townsville

Schaffelke B, Klumpp DW (1997a) Biomass and productivity of tropical macroalgae on three nearshore fringing reefs in the central Great Barrier Reef, Australia. Bot Mar 40: $373-383$

Schaffelke B, Klumpp DW (1997b) Growth of germlings of the

Editorial responsibility: Daniel Alongi (Contributing Editor), Townsville, Australia macroalga Sargassum baccularia (Phaeophyta) is stimulated by enhanced nutrients. Proc 8th Int Coral Reef Symp 2:1839-1842

Schramm W, Abele D, Breuer G (1988) Nitrogen and phosphofus nutrition and productivity of two community forming seaweeds (Fucus vesiculosus, Phycodrys rubens) from the western Baltic (Kiel Bight) in the light of eutrophication processes. Kiel Meeresforsch Sonderh 6:221-240

Scott FJ, Russ GR (1987) Effects of grazing on species composition of the epilithic algal community on coral reefs of the central Great Barrier Reef. Mar Ecol Prog Ser 39:293-304

Smith SV (1981) The Houtman Abrolhos lslands: carbon metabolism of coral reefs of high latitude. Limnol Oceanogr 26:612-621

Smith SV (1984) Phosphorus versus nitrogen limitation in the marine environment. Limnol Oceanogr 29:1149-1160

Smith SV, Kimmerer WJ, Laws EA, Brock RE, Walsh TW (1981) Kaneohe Bay sewage diversion experiment: perspectives on ecosystem responses to nutritional perturbation. Pac Sci 35:84-92

Starr RC, Zeikus JA (1993) UTEX - the culture collection of algae at the University of Texas at Austin. J Phycol 29 (Suppl) : 1-106

Staunton Smith J, Johnson CR (1995) Nutrient inputs from seabirds and humans on a populated coral cay. Mar Ecol Prog Ser 124:189-200

Szmant AM, Forrester A (1996) Water column and sediment nitrogen and phosphorus distribution patterns in the Florida Keys, USA. Coral Reefs 15:21-41

Thomas TE, Harrison PJ, Turpin DH (1987) Adaptations of Gracilaria pacifica (Rhodophyta) to nitrogen procurements at different tidal locations. Mar Biol 93:569-580

Vuki VC: Price IR (1994) Seasonal changes in the Sargassum populations on a fringing coral reef, Magnetic Island, Great Barrier Reef region, Australia. Aquat Bot 48: $153-166$

Waite TD, Mitchell R (1972) The effect of nutrient fertilisation on the benthic alga Ulva lactuca. Bot Mar 15:151-156

Wallentinus I (1984) Comparisons of nutrient uptake rates for Baltic macroalgae with different thallus morphologies. Mar Biol 80:215-225

Waish RS, Hunter KA (1992) Influence of phosphorus storage on the uptake of cadmium by the marine alga Macrocystis pyrifera. Limnol Oceanogr 37:1361-1369

Wilkinson GN (1961) Statistical estimations in enzyme kinetics. Biochem J 80:324-332

Submitted: August 8, 1997; Accepted: January 7, 1998

Proofs received from author(s): March 11, 1998 